only few trees at the Allerød-YD transition, does not show marked changes in summer growth conditions. The decrease of ostracode $\delta^{18} \mathrm{O}$ by $1.9 \%$ indicates a $5^{\circ} \mathrm{C}$ mean temperature reduction from late Allerød to YD conditions (Burns \& Schwalb, unpublished data). In contrast to the transition displayed by proxies of Lake Constance, the Allerød-YD transition in LMM is very distinct and comparable to the fastYD-Preboreal transition seen in all proxies. Rapidly increasing $\delta^{13} \mathrm{C}$ values in the organic matter $\left(\delta^{13} \mathrm{C}_{\mathrm{OM}}\right)$ in LMM sediments at the Allerød-YD transition indicate increased lacustrine primary production. Carbon isotope values remain high during the YD and can only be explained by relatively warm summer temperatures (Lücke and Brauer, 2004), which is in good agreement with moderate mean ring-width during centralYD.

Thus, it evolves that the AllerødYD transition, and in turn the YD, may be characterized by increased seasonality. Since summer temperatures and the duration of the vegetation period allow moderate tree growth, the temperature reduction may be ascribed to the winter period. This is in accordance with results from southern Greenland (Björck et al., 2002) and from the Swiss Alps (Lotter et al., 2000).

Regarding the climatic characteristics of the YD-stadial, our proxies suggest a climatically variable
YD with distinct climatic phases. Both ostracode species of Lake Constance show minima of mean temperatures in the centralYD. Decreasing ring-width towards the end ofYD, accompanied by pronounced accumulation of missing rings and frost rings (even in late or summer wood) between 11,850-11,600 BP, indicate clear deterioration of summer growth conditions towards the end of the YD. Taking into account the accumulation rates of minerogenic matter in LMM sediments, which indicate a strong increase of snowmelt run-off in spring after 12,250 $\mathrm{BP}$, and the decreasing $\delta^{13} \mathrm{C}_{\mathrm{OM}}$ values after $12,100 \mathrm{BP}$, this may indicate cooler and/or more cloudy summers and snow-rich winters in the second part of the YD.

\section{Conclusion and Outlook}

Extensions and improvements of tree-ring chronologies into the Late Glacial along with radiocarbon calibration and the dendro-date of the LST allowed the accurate synchronization of tree-ring and lacustrine sediment archives. As an example of an integrative approach combining different proxy records from our archives, we could demonstrate that the climatic development of the YD is probably not homogenous but divided into different climatic phases. In this respect, changes in seasonality seem to play an important role.

Further insights into natural climate change are anticipated from an extended network of accurate synchronized archives and a close cooperation with the recently granted DEKLIM modeling project "MIDHOL" which will help to evaluate hypotheses derived from synchronized Late Glacial and Holocene records.

\section{Acknowledgements}

Radiocarbon work was done in cooperation with B. Kromer, Heidelberg Academy of Science, Germany (DEKLIM project). K.-F. Kaiser, WSL Birmensdorf, Switzerland and the Laboratoire Romand de Dendrochronologie, Moudon, Switzerland provided additional Late Glacial tree-ring data. Investigations on Lake Meerfelder Maar are shared with A. Brauer, Geoforschungszentrum Potsdam, Germany.

\section{References}

Friedrich, M., Remmele, S., Kromer, B., Spurk, M., Hofmann, J., Hurni, J.P., Kaiser, K.F. and Küppers, M., in press: The 12,460-year Hohenheim oak and pine tree-ring chronology from Central Europe - A unique annual record for radiocarbon calibration and palaeoenvironment reconstructions, Radiocarbon.

Kromer, B., Friedrich, M., Hughen, K.A., Kaiser, K.F., Remmele, S., Schaub, M. and Talamo, S., in press: Late Glacial/Early Younger Dryas 14C ages derived from floating Central European tree-ring chronologies, Radiocarbon

Lücke, A., and Brauer, A., 2004: Biogeochemical and micro-facial fingerprints of ecosystem response to rapid Late Glacial climatic changes in varved sediments of Meerfelder Maar (Germany). Palaeogeography, Palaeoclimatology, Palaeoecology 211 (1-2), 139-155.

Schwalb, A., 2003: Lacustrine ostracodes as stable isotope recorders of late-glacial and holocene environmental dynamics and climate. Journal of Paleolimnology 29, 265-351.

For full references please consult: www.pages-igbp.org/products/newsletters/ref2004_2.html

\title{
The Global Carbon Cycle During the Last Glacial/Interglacial Transition
}

\section{H. Fischer, P. Köhler J. Schmitt and F. Fundel \\ Young Scientist Research Group for Earth Climate System Reconstructions on Polar Ice Cores (RESPIC), Alfred Wegener Institute for Polar and Marine Research, Columbusstrasse, 27515 Bremerhaven, Germany; hufischer@awi-bremerhaven.de, pkoehler@awi-bremerhaven.de,} jschmitt@awi-bremerhaven.de.ffundel@awi-bremerhaven.de

The global carbon cycle has played a significant role both in recent climate changes as well as in glacial/ interglacial (G/IG) transitions. Carbon reservoirs and exchange rates are affected by external climate conditions and conversely, changes in atmospheric $\mathrm{CO}_{2}$ concentrations lead to amplification and mediation of regional climate variations. The major goal of RESPIC is the quantification of changes in the global carbon cycle and its connec- tion to climate changes over the last glacial cycle, using a new model as well as improved (proxy) validation data for boundary conditions in the past. Here, especially, new ${ }^{13} \mathrm{CO}_{2}$ data from Antarctic ice cores represent an urgently needed constraint to complement the ice core $\mathrm{CO}_{2}$ concentration record, and are a main focus of RESPIC. In addition, aerosol records from polar ice cores provide valuable information, e.g. on dust-derived iron fertilization of the high latitude surface ocean and on biological activity in terrestrial and marine ecosystems, and are also being investigated by RESPIC. Thus, RESPIC contributes to the quantification of climate variability in the past, to the understanding of the processes coupling climate and the carbon cycle, necessary to improve climate models, and, therefore, to major objectives of DEKLIM.

Here, we focus on transient model studies to elucidate G/IG 


\section{Science Highlights: DEKLIM}

changes in the carbon cycle. Time slice experiments have so far been unable to unambiguously explain the driving forces of the $\mathrm{G} / \mathrm{IG}$ change in atmospheric $\mathrm{pCO}_{2}$ of about 100 ppmv. Additional information can be gained from studying the temporal evolution of the carbon cycle using transient model runs, which allows us to disentangle different forcing factors. By forcing a coupled ocean-atmosphere-biosphere box model (Fig. 1) of the global carbon cycle with proxy data spanning the last glacial termination, we have for the first time been able to quantitatively reproduce transient variations in $\mathrm{CO}_{2}$ and $\delta^{13} \mathrm{CO}_{2}$ observed in ice cores, both in time and magnitude (Fig. 2). According to our model, various factors such as reduced iron fertilization, ocean circulation and stratification, as well as sea ice coverage of the Southern Ocean, contributed to the overall G/ IG change at different times. (Köhler et al., 2004, Smith et al. 1999). Thus, initial processes during deglaciation in the Southern Ocean, followed by the 1500 year delayed kick-in of the thermohaline circulation (THC) in the North Atlantic (as revealed in the DEKLIM project CliTrans, Knorr and Lohmann, 2003) are consistent with atmospheric carbon records. In

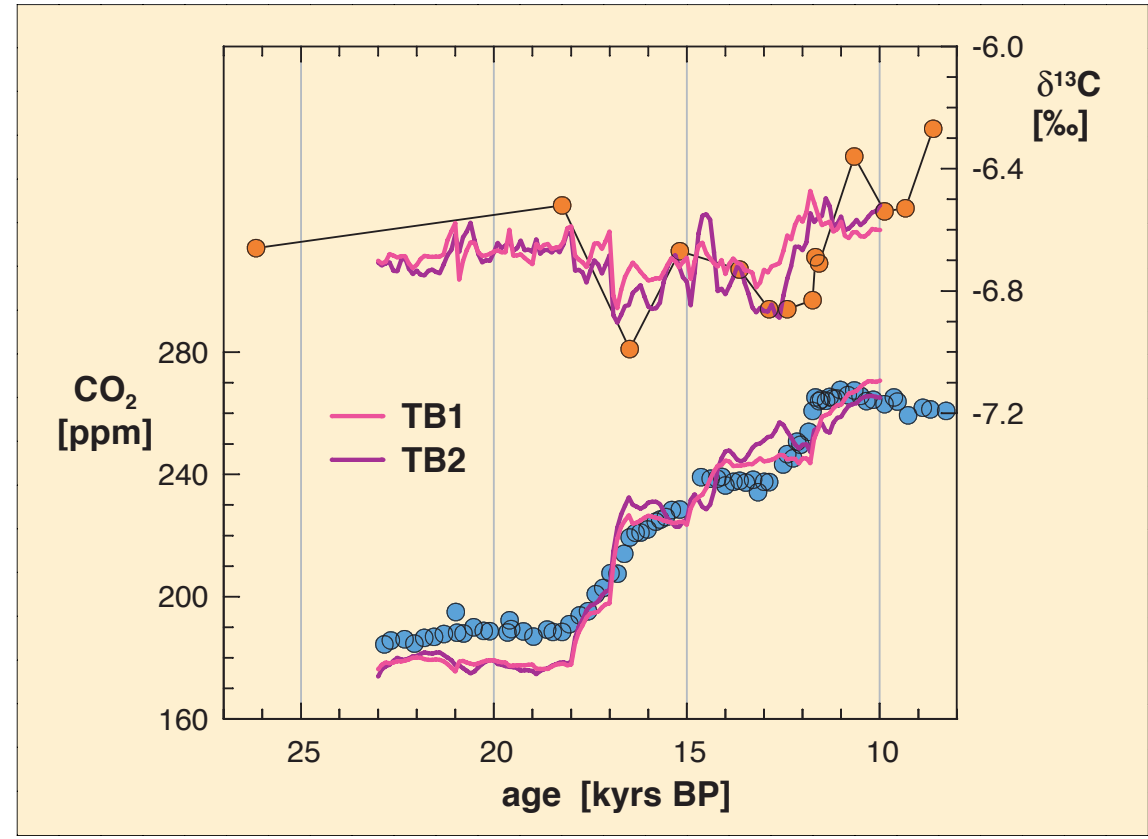

Fig. 2: Carbon records simulated with BICYCLE compared with $\delta^{13} \mathrm{C}$ (orange) and $\mathrm{CO}_{2}$ (b/ue) data (Smith et al., 1999, Monnin et al., 2001). Simulation scenarios combine all climate processes with changes in $\mathrm{THC}$, marine export production, $\mathrm{CaCO}_{3}$ compensation and terrestrial biosphere with two different realizations for the regrowth of vegetation on land (TB1: dominated by $\mathrm{CO}_{2}$ fertilization; TB2: dominated by climate change). addition, the significant influence of the terrestrial biosphere on changes in the isotopic composition of atmospheric $\mathrm{pCO}_{2}$ during the second half of the termination is supported, and together with the contribution of carbonate compensation, fully explains the observed increase in $\mathrm{pCO}_{2}$.

Further insight into changes in the carbon cycle can be expected from temporally better resolved and

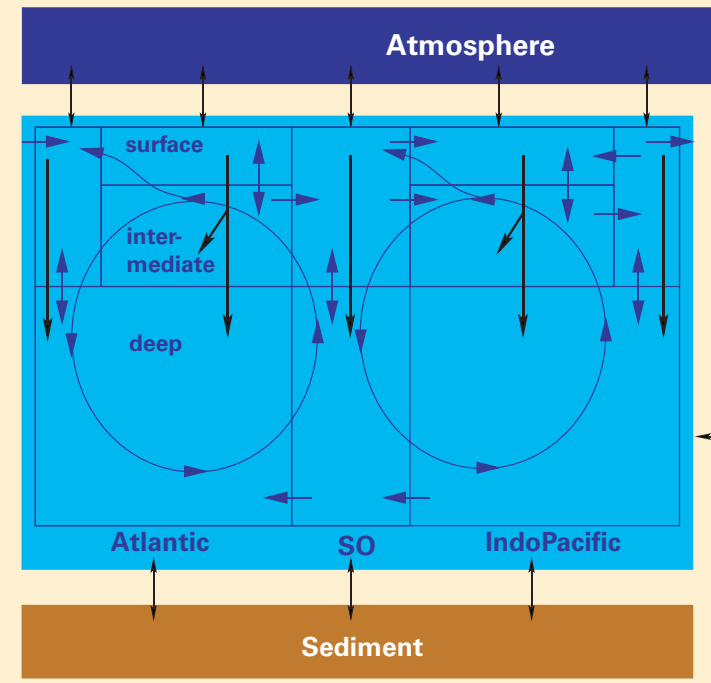

Box model of the Isotopic Carbon Cycle

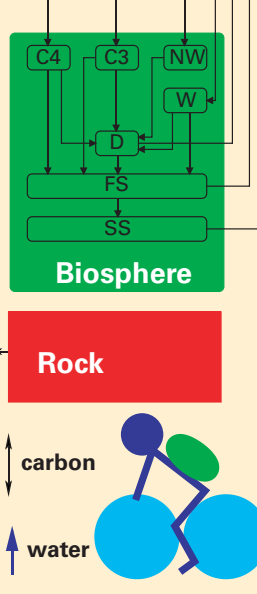

BICYCLE
Fig. 1: Structure of the model BICYCLE (Box model of the Isotopic Carbon cycle). Our terres trial biosphere internal module (Köhler and Fischer, 2004) or other model output can be used. Arrows indicate the fluxes of carbon. more accurate $\delta^{13} \mathrm{CO}_{2}$ data derived from Antarctic ice cores. To this end, RESPIC is currently developing new sample extraction and mass spectrometric techniques for high precision $\delta^{13} \mathrm{CO}_{2}$ analyses on small air samples from deep clathrate ice. These techniques will be employed on samples from the new ice cores currently being drilled within the framework of the European Project for lce Coring in Antarctica (EPICA), providing the first atmospheric records covering the last 800,000 years (EPICA community members, 2004).

\section{REFERENCES}

EPICA community members, 2004: Eight glacial cycles from an Antarctic ice core, Nature 429, 623-628.

Knorr, G. and Lohmann, G., 2003: Southern Ocean origin for the resumption of Atlantic thermohaline circulation during deglaciation. Nature $\mathbf{4 2 4}$, 532-536.

Köhler, P. and Fischer, H. 2004: Simulating changes in the terrestrial biosphere during the last glacial/interglacial transition, Global and Planetary Change, doi: 10.1016/j.gloplacha.2004.02.005.

Köhler, P., Fischer, H. and Zeebe, R. E., submitted: Quantitative interpretation of atmospheric carbon records over the last glacial termination. Global Biogechemical Cycles.

Monnin, E., Indermühle, A., Dällenbach, A., Flückiger, J., Stauffer, B., Stocker, T. F., Raynaud, D., and Barnola, J.-M., 2001: Atmospheric $\mathrm{CO}_{2}$ concentrations over the Last Glacial Termination. Science 291, 112-114.

Smith, H. J., Fischer, H., Wahlen, M., Mastroianni, D., and Deck, B., 1999: Dual modes of the carbon cycle since the Last Glacial Maximum. Nature $\mathbf{4 0 0}$, 248-250. 